\title{
On the squamation of Australerpeton cosgriffi Barberena, a temnospondyl amphibian from the Upper Permian of Brazil
}

\author{
ELISEU V. DIAS and MARTHA RICHTER \\ Universidade Federal do Rio Grande do Sul, Instituto de Geociências \\ 91509-900 Porto Alegre, RS, Brasil \\ Manuscript received on March 5, 2001; accepted for publication on February 26, 2002; \\ presented by MiLTon Formoso
}

\begin{abstract}
Abdominal scales of a juvenile specimen of Australerpeton cosgriffi Barberena 1998 are made of primary compact bone rich in osteocyte lacunae; vascular canals and primary osteons are rare with no sign of remodelling of the tissue by resorption and redeposition. In contrast, the abdominal scales of an adult of the same species shows extensive reworking of the bone tissue. The scale grows by apposition of lamellar bone peripherally around the whole scale; the presence of Sharpey fibers in the periphery of the scales both basally and externally suggests that they remained deeply embedded in the dermis; the embryonic scale is completely remodelled in the adult by resorption and redeposition which produces a cancellous bone with large erosion bays and secondary osteons. Remodelling by resorption and redeposition is confined to the core of the scales and does not affect its periphery, contrary to what happens in sarcopterygians with cosmoid scales. The possible biological functions of the squamation in this species, such as mechanical protection, dry protection, cutaneous respiration, hydrostatic control and calcium reservoir, are discussed.
\end{abstract}

Key words: Temnospondyli, paleohistology, paleobiology, Upper Permian, Rio do Rasto Formation.

\section{INTRODUCTION}

Rhomboid or round dermal scales are known in many fossil amphibians of distinct groups within the Temnospondyli such as the Colosteids, Rhinesuchoids, Archegosauroids, Trematosauroids and Dissorophoids. The other primitive tetrapod lineage, the anthracosaurs (sensu Gauthier et al. 1988) possessed a very well developed scale covering, a condition found for example in Eogyrinus attheyi Watson 1926 and in Crassigyrinus scoticus Watson 1929 where the scales cover almost the entire body. Basal tetrapods like Tulerpeton curtum Lebe-

Correspondence to: Eliseu Vieira Dias

E-mail: eliseu.dias@ufrgs.br dev 1984 also possessed a scale cover (Lebedev and Coates 1995). This points to the primitiveness of the scale presence in tetrapods and it seems to be a remnant character from Osteolepiformes fishes, although their scales differ quite substantially in terms of histological features. Tetrapod dermal bones lack enamel and dentine tissues, for instance, although most living fishes (both sarcopterygians and actinopterigians) also do, a condition acquired independently. No amphibian known so far shows dermal denticles (odontodes) in the squamation. Amphibians and higher vertebrates apparently lost the capacity, seen in fishes, of the trunk neural crest cells to make teeth and odontodes; only the cranial neural 
crest presumably expresses itself forming oral teeth and, in certain groups like the urodels and some temnospondils, tooth-bearing pharyngeal plates (Graveson et al. 1997, Coates 1996). Consequently, the dermal bones and squamation of tetrapods are made up exclusively of bone tissue.

In modern amphibians scales occur in the Gymnophiona but their morphological pattern, as described by Zylberberg et al. (1980), is by far different from that found in the Temnospondyli amphibian Australerpeton cosgriffi.

Hook (1983) gave an account of the squamation of some early tetrapods including Colosteus scutelatus Newberry 1856 from the Carboniferous of the North America. He discussed the various terms used to describe the elements of the tetrapod 'armour' and made a muddled distinction between scales and osteoderms, basically pointing out the fact that both are structures formed within the dermis, the former presumably deeper and the latter more superficially but Hook (1983) did not specify how to quantify this depth. In fact there is no clear functional anatomical distinction that justifies choosing between either of these terms in the case of dermal ossifications of these primitive amphibians.

Romer (1956) treated the ventral scales of Paleozoic amphibians and those of bony fish as homologous by having an essentially protective function and also homologous in development, because for him, the dermis tends to retain its primitive potentiality of forming bone, and a great number of independent groups of tetrapods developed dermal ossifications using this potentiality.

Moreover, Hook (1983), like Romer (1956), treated the ventral scales as forerunners of the gastralia, the "abdominal ribs" of some primitive tetrapods. There is no consensus about this interpertation but many authors treat the ventral scales of primitive tetrapods as gastralia. Laurin (1996) described the gastralia of a seymouriamorph as been composed of several scale rows that meet in the midline at a sharp angle. Milner and Sequeira (1994) also describe a gastralia, composed of elliptical scales, for a temnospondyl amphibian. Following this inter- pretation, this "gastralia" composed of scales could be homologous with the dermal abdominal ribs of more derived animals.

In conclusion, all the terms, osteoderms, scales or gastralia, refer to dermal ossifications and there are no clear distinctions between them. The scales or osteoderms of the rhinesuchoid Australerpeton cosgriffi, resemble fish scales in various aspects and here they are called scales for the sake of simplicity.

No fossil amphibian scales have been described from Brazil up to date. The good preservation of the hard tissues of the specimens and the availability of two individuals of different sizes led us to investigate the structure and histology of the squamation of Australerpeton cosgriffi, a species only known from the continental Rio do Rasto Formation (Upper Permian) of the Paraná Basin in southern Brazil (Barberena 1998).

The dermal bones and scales of primitive amphibians are known to be highly vascularized and highly reworked through resorption and redeposition of the bone tissue (e.g. Bystrow 1935, Cosgriff and Zawiskie 1979). However, comparative histological studies of amphibians scales are rare.

Thin sections of amphibian long bones such as femora have shown that the skeletal growth follows a pattern similar to modern crocodiles. In both, amphibians and crocodilies, these bones have growth lines that can be used to estimate the minimal age of each individual. The type of bone organization can also provide evidences for ecological inferences (Damiani 2000).

\section{MATERIAL}

The skeletons were collected at outcrops of the Rio do Rasto Formation along the Ponta Grossa - Apucarana railroad (Serra do Cadeado region) in the Paraná State (Fig. 1) by Dr. M. C. Barberena and his colleagues at the Universidade Federal do Rio Grande do Sul (UFRGS) at the beginning of the 1980s. Two specimens were used for this study:

- UFRGS-PV0319P: A specimen represented by a fragment of the skull table, an almost com- 


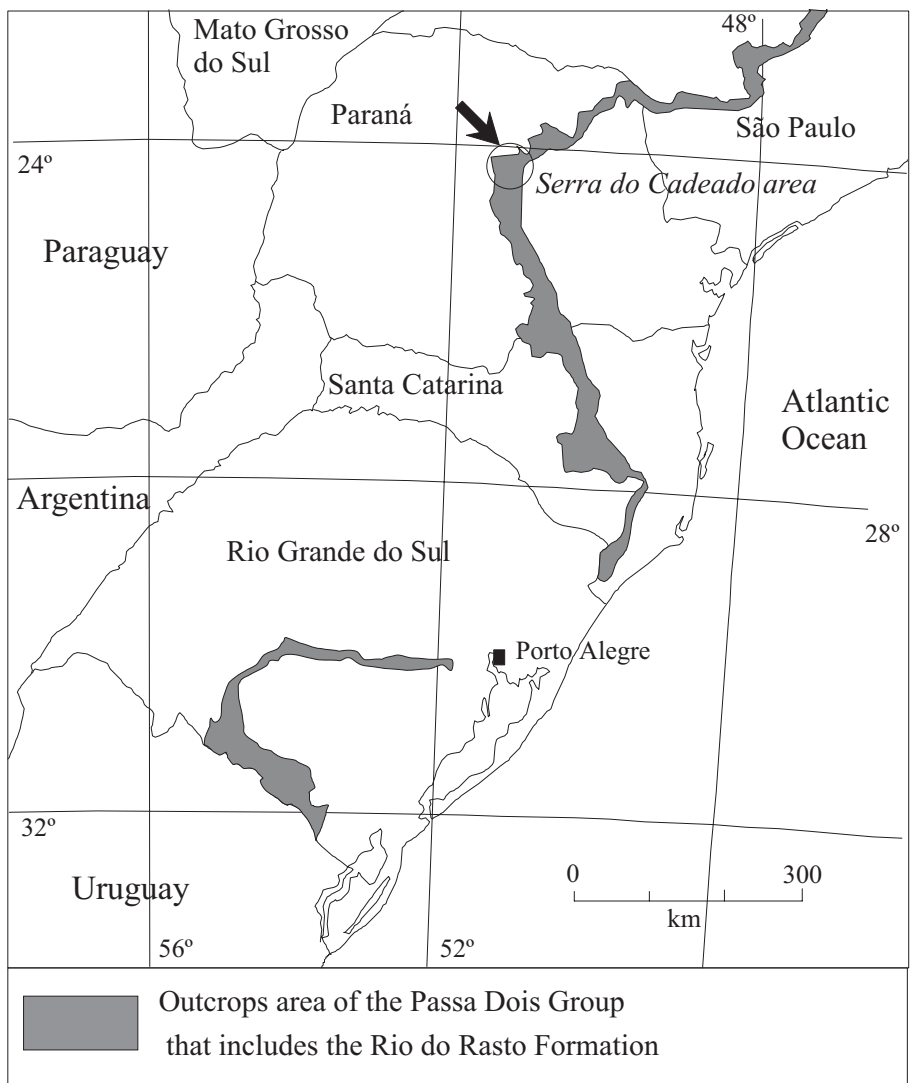

Fig. 1 - Location map of the Serra do Cadeado region in the State of Paraná, southern Brazil.

plete vertebral column, some bones of the girdles and also some articulated scales.

- UFRGS-PV0320P: An individual with the posterior part of the skull, many post-cranial bones and some isolated scales.

Within the fossil assemblage of the Rio do Rasto Formation in the Serra do Cadeado area there are only two known temnospondyl morphotypes. The long-snouted morphotype is attributed to Australerpeton cosgriffi (Barberena et al. 1985, Barberena 1998) while the short-snouted morphotype remains unidentified (Barberena and Dias 1998) The material used for histological studies herein was identified as Australerpeton cosgriffi mainly based on the morphology of the associated skeletal remains preserved on both specimens. The skull frag- ments of UFRGS-PV0319P and PV0320P fit better on the long-snouted morphotype. Besides, postcranial bones (e.g. femur and clavicle) also differ from those associated with the short-snouted morphotype.

Bageherpeton longignathus Dias and Barberena 2001, another long-snouted temnospondyl from the Rio do Rasto Formation (Dias and Barberena 2001) was discarded, because it came from a distinct geographic and stratigraphic position. It was found in the Rio Grande do Sul State and in upper levels within the Rio do Rasto Formation (Barberena et al. 1985).

In the amphibian collection at UFRGS yielded by the Rio do Rasto Formation at the Serra do Cadeado, there are specimens of Australerpeton cosgriffi of distinct sizes, suggesting the presence of an- 
imals of various ages in the thaphocenosis. We have no evidence to believe that UFRGS-PV0319P and PV0320P could represent two biological species. On the contrary, most of the post-cranium remains are similar in both individuals and their small differences can be more easily interpreted as ontogenetical or, less probably, due to sexual dimorphism. The histological evidence described in this paper supports the hypothesis of different ontogenetic stages (see discussion). In the post-cranium, the pleurocentra are not very well ossified in the smaller specimen and very well developed in the bigger one. Notwithstanding, the discussion of the postcranial characters is beyond the scope of this paper and will be presented in a future work (Dias and Schultz, in preparation). Concluding, we assume that UFRGS-PV0319P is a young specimen, while UFRGS-PV0320P is older and may be an adult.

For comparison of the dermal skull roof we used a specimen of the crocodilian Caiman sp. from Rio Grande do Sul State in the teaching collection of the Vertebrate Paleontology Laboratory, as well as the original type series published by Barberena (1998) and other partially preserved skulls of Australerpeton cosgriffi (UFRGS-PV0237P; UFRGSPV0320P).

\section{DESCRIPTION}

\section{General Morphology and Distribution}

\section{of THE SQUamation}

The osteological description of both specimens whose scale histology is described here will be presented elsewhere (Dias and Schultz, in preparation). Most elements of the post-cranium are well preserved and some of them kept their anatomical position in both specimens. Unfortunately, most of the scales were dislodged during fossilization, principally in the adult specimen, so that the original distribution of the scales is poorly preserved and prevents a precise reconstruction of the full squamation in both individuals. However, small blocks of articulated scales were fossilized in the ventral region of the younger specimen, giving information on their mode of articulation. The scales were present mainly in the ventral region of the animal as commonly found in Temnospondyli. The anteriormost scale row is in the neck region and the most posterior one is apparently at the level of the pelvic girdle. The scales are rhombic in general shape but they vary a little in size and shape throughout the individual.

UFRGS-PV0319P - an young individual of Australerpeton cosgriffi (Fig. 2A-C).

At least four assemblages of articulated scales are preserved ventrally to the vertebral column. No evidence of dorsal scales was found so the scales cover only the ventral surface of the animal.

Near the cervical region, the scales are about $18 \mathrm{~mm}$ long and their width ranges from 2 to $4 \mathrm{~mm}$. They are elongated thin bars, ornamented with long and shallow longitudinal grooves. In the anterior part of the abdominal region, the scales are slightly larger than the anterior ones, measuring 6 to $9 \mathrm{~mm}$ in width but with almost the same length, $18 \mathrm{~mm}$. In the posterior part of the abdominal region the scales become smaller, ranging from 11 to $14 \mathrm{~mm}$ in length and $4 \mathrm{~mm}$ in width. The outline of an isolated scale of this region is a trapezoid, in which the bigger base is the anterolateral edge and the smaller is the posterior edge (Fig. 2A). When articulated, the exposed surface is lozenge shaped representing almost half of the total area of the entire scale (Fig. 2B). The other half of the scale is excavated anteriomedially, forming an internal articular process that accommodates the preceding overlapping scale. The external ornamentation is less pronounced in the abdominal than in the neck scales and all scales show few blood vessels crossing the outer surface. At the level of the scapular girdle, there are some articulated scales preserved in internal view. Their external area is almost square shaped and the surface seems to be smooth with very small foramina for blood vessels. The anterior overlapping surface shows some fine furrows and a variable number of short nodules, measuring no more than $1 \mathrm{~mm}$ each (Fig. 2A).

UFRGS-PV0320P - an adult individual of Australerpeton cosgriffi. 

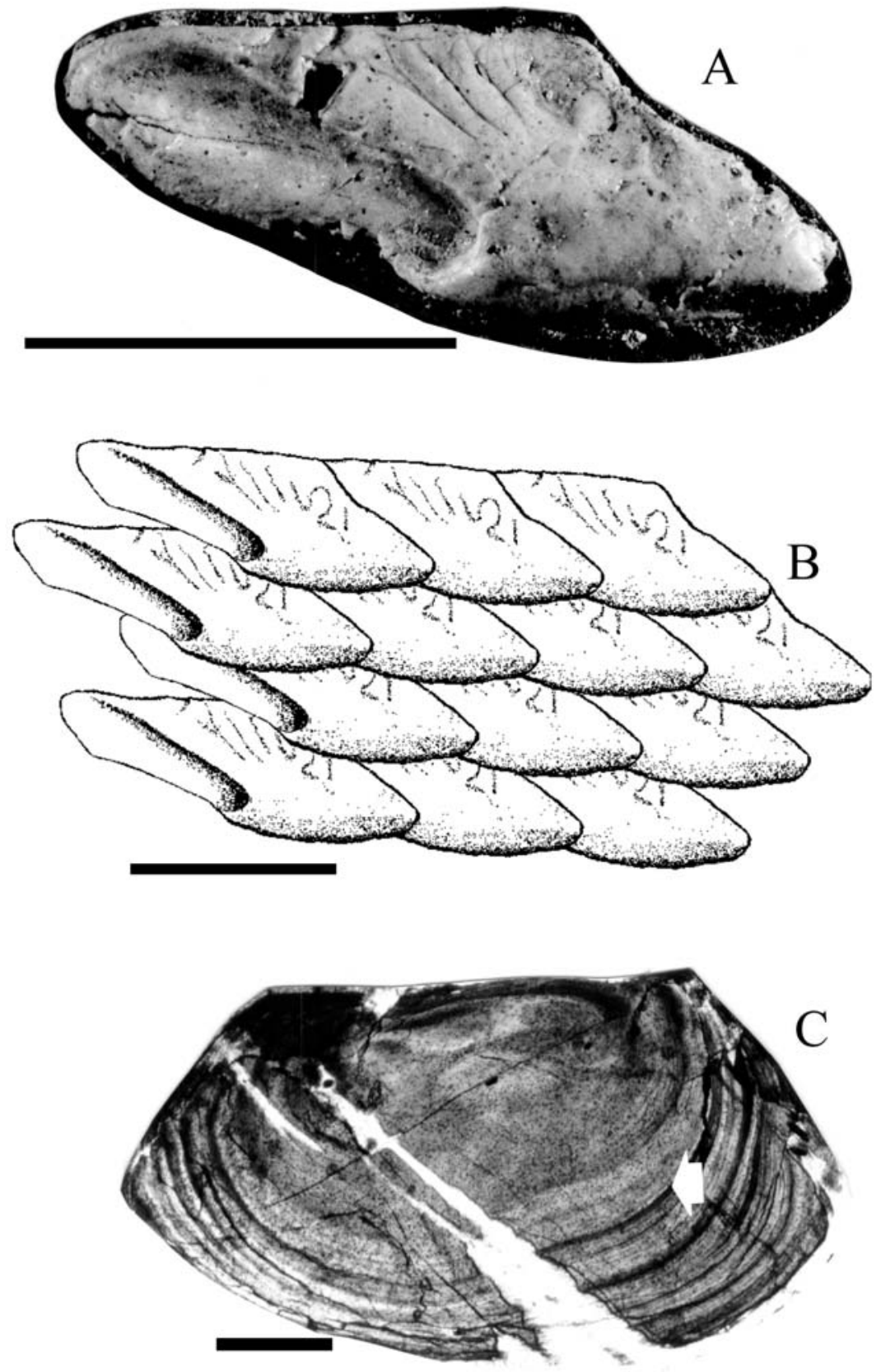

Fig. 2-Abdominal scales of a presumed juvenile specimen of Australerpeton cosgriffi Barberena 1998; A. external view of an isolated scale of specimen UFRGS-PV0319P. Scale bar $=1 \mathrm{~cm}$; B. reconstruction based on the same scale showing the articulation pattern. Scale bar $=1 \mathrm{~cm}$; C. Histological features observed in a vertical section showing growth lines (arrow) and the embryonic scale of compact bone. Scale bar $=1 \mathrm{~mm}$. 
The scales of the adult are variable in size (20$29 \mathrm{~mm}$ long and 8-12 mm wide) and in ornamentation. The trapezoid shape of the scales in the younger specimen develops into a more ellipsoid one in the adult. Frequently, a large number of fine blood vessels, lodged in furrows, cross the internal surface of the scale in an almost radial pattern and they converge to a main region of entrance to the scale core (Fig. 3A). Externally, the scales show an irregular ornamentation consisting of nodules and some transverse crests and a very small number of vascular openings coming to the out side (Fig. 3B, C and D).

The dermal bones of Australerpeton cosgriffi show only a single small foramen for each pit or groove (Fig. 3E). This pattern is similar in Caiman sp. (Fig. 3F).

\section{Histological Features of the Scales}

Seven thin sections of dermal scales from these two specimens of Australerpeton cosgriffi were made and are described below.

1. Specimen UFRGS-PV0319P (a young specimen).

Scale histology. Vertical sections of an isolated scale and of some articulated scales were made. All the scales consist of lamellar (compact) bone throughout (Fig. 2C). Primary osteons and vascular canals are rare. The tissue shows a very high density of osteocyte spaces and Sharpey fibers, which are distributed at nearly right angles to the entire surface.

Growth lines. There are at least five wellmarked interruptions in the formation of the bone which are interpreted as growth lines. The shape of the scales is only slightly altered by growth, judging by the course of the growth lines, which are parallel to the former (older) surfaces. There is no evidence of remodelling of the bone tissue in this specimen (Fig. 2C).

Vascularization. Very few vascular canals of small calibre run across the scale reaching out the surface.
2. Specimen UFRGS-PV0320P (Figs. 4A-C and 5A-E) (an adult specimen).

Scale histology. Transverse thin sections of articulated scales of this specimen show that all of them are entirely made up of cellular bone highly remodelled by resorption and redeposition internally. The bone tissue is compact peripherally and cancellous in the core of the scale (Fig. 4A, B and C). The articulation area is composed mainly of compact bone (Fig. 4C). The osteocyte lacunae are usually well preserved (Fig. 5C). Resorption is therefore confined to the ontogenetically older bony layers of the scale and affects areas of primary lamellar bone as well as primary osteons. Redeposition occurs around vascular cavities forming secondary osteons. Resorption also forms larger cavities which often truncate primary and secondary osteons leading to total remodelling of the embryonic scale (Fig. 5B). Vascular canals crossing the scales in all directions suggest that these were deeply embedded in the dermis. The periphery of the scales contains a large concentration of Sharpey fibber bundles, both basally, laterally and superficially (Figs. 4B; 5A, D and $\mathrm{E}$ ) which also indicates that they were deeply embedded in the dermis.

Growth lines. At least nine growth marked events were counted in the most peripheral parts of the scales which are not too badly affected by reworking of the bone tissue. The core of the scales, corresponding to the embryonic scale, is the site more heavily affected by resoption and redeposition and also contains the largest vascular cavities (Fig. 4A, B).

Vascularization. The vascular pattern of this scale inferred by the thin sections suggests that most vascular canals run longitudinally in irregular or in circular rows, giving a trabecular appearance to inner portion of the scale, which some authors describe as a "honeycomb" bone structure (Cosgriff and Zawiskie 1979). This richly vascularized middle portion has only a reduced number of vascular communications to outside. Most of the blood supply is therefore provided by the vessels coming from the inner side (Fig. 4A, B and C). 

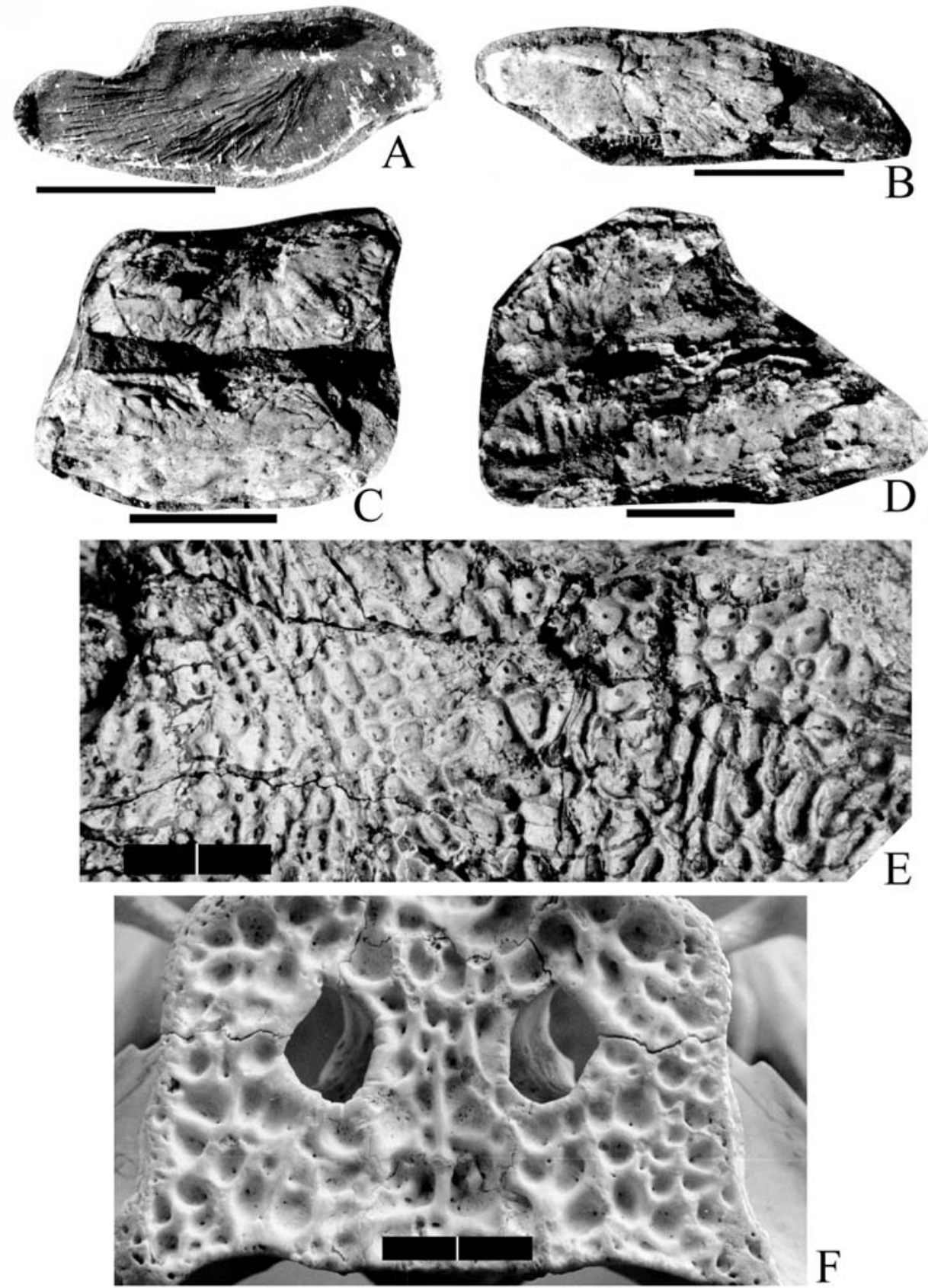

Fig. 3 -A. Cast of the internal surface of a scale of the adult specimen of Australerpeton cosgriff Barberena 1998 (specimen UFRGSPV0320P) showing the radial pattern of furrows produced by blood vessels; B, C and D. External view of adult scales showing ornamentation made up of irregular nodules and crests and the small number of blood vessels reaching out the scale surface. Scale bars $=1 \mathrm{~cm}$. E. External view of the skull table of Australerpeton cosgriffi (UFRGS-PV0237P). Scale bar $=2 \mathrm{~cm}$. F. External view of the skull table of Caiman sp.. Scale bar $=2 \mathrm{~cm}$. E and F show the pattern of dermal bone ornamentation with a single foramen for each pit or groove. 


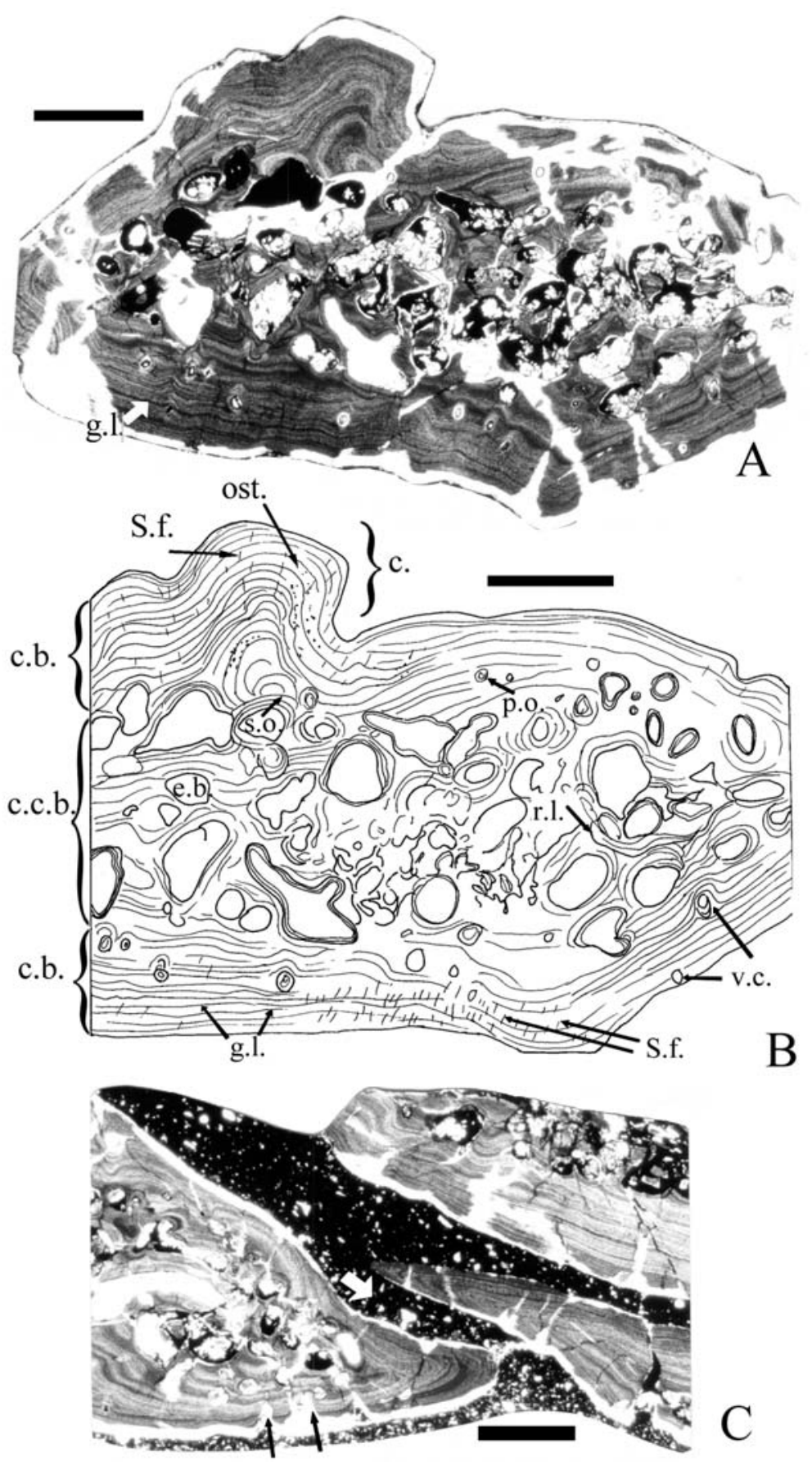

Fig. 4 - Histological features of abdominal scales of UFRGS-PV0320P, an adult specimen of Australerpeton cosgriffi Barberena 1998. A. Cross section. Scale bar $=1 \mathrm{~mm}$. B. corresponding drawing; c. crest of external ornamentation; c.b. compact bone; c.c.b., cancellous compact bone; e.b. erosion bay; g.l. growth lines; ost. osteocyte lacunae; p.o. primary osteon; r.l. resorption (reversal) line; S.f. Sharpey fibers; s.o. secondary osteon; v.c. vascular canal. C. Articulated scales showing the area of articulation of two scales (white arrow), as well as large number of vascular canals in the inner side (bottom black arrows) running to the cancellous bone and few of them running to outside. Scale bar $=1 \mathrm{~mm}$. 

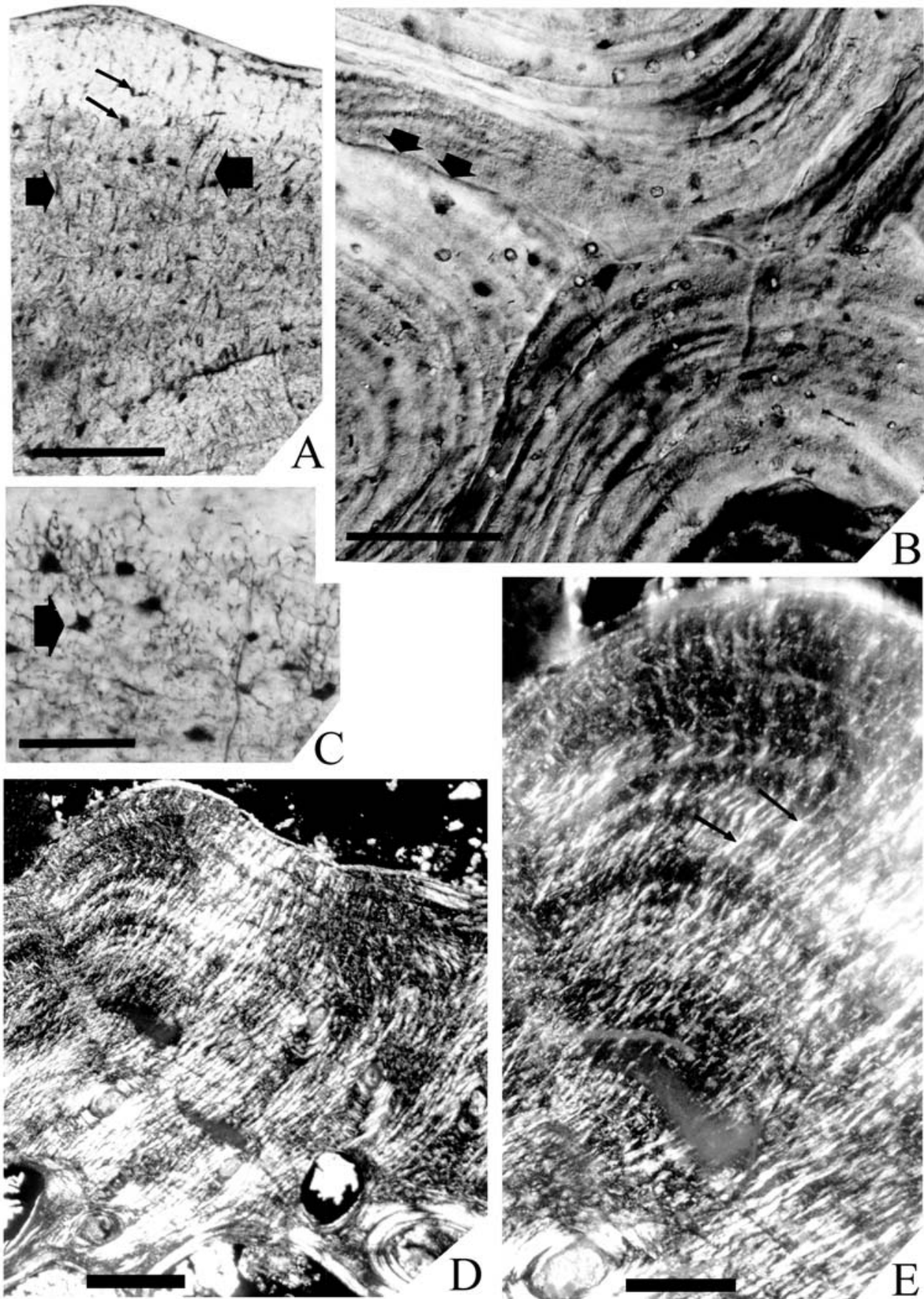

Fig. 5 - Histological features of an abdominal scale of the adult specimen of Australerpeton cosgriffi Barberena 1998. (UFRGSPV0320P). A. Peripheral region of the scale showing osteocyte lacunae (small arrows) and Sharpey fibers (big arrows). Scale bar $=100 \mu \mathrm{m} ; \mathbf{B}$. Resorption lines (arrows) between three osteons. Scale bar $=50 \mu \mathrm{m}$. C. Detail of osteocyte lacunae (arrow) common throughout the scale. Scale bar $=50 \mu \mathrm{m}$. D and E. Peripheral area of the scale under polarized light. D. The extensive distribution of Sharpey fibers in the peripheral compact bone as well as in the external limits of the cancellous core. Scale bar $=500 \mu \mathrm{m}$. E. Detail of the Sharpey fibers (arrows) crossing many growth lines in a crest of the external ornamentation. Scale bar $=250 \mu \mathrm{m}$. 


\section{DISCUSSION}

The systematic value of dermal scales of Paleozoic amphibians is limited at present, since the scales of most temnospondyl genera are either usually not well described or unknown. Detailed descriptions and histological studies may provide new characters for systematic studies.

The external morphology of the scales of a young Australeperton cosgriffi is basically similar to patterns found in other temnospondyls such as Platyoposaurus stuckenbergi Trautschold 1884 and Uranocentrodon (Rhinesuchus) senekalensis Van Hoepen 1915. The scales are not so elongated in Australerpeton as they are in U. senekalensis (Van Hoepen 1915, Findlay 1968). The shape and size of isolated scales of the younger specimen of Australerpeton cosgriffi are similar to the scales of Platyoposaurus stuckenbergi described by Konzhukova (1955 drawings $\beta$ and $\delta$ ).

The articulation pattern for Uranocentrodon senekalensis described by Findlay (1968) is similar to that of $A$. cosgriffi, with an elongated articular process in which the articular surface is overlapped by the mesial scales.

The chevron - an inverted- $\mathrm{V}$ distribution pattern for the ventral scales - is common in primitive tetrapods. Many authors described this pattern in distinct taxa (e. g. Konzhukova 1955 for Platyoposaurus stuckenbergi; Findlay 1968 in Uranocentrodon senekalensis; Hook 1983 for Colosteus scutellatus) Unfortunately, due to taphonomic conditions, the scales of Australerpeton cosgriffi are scattered in small blocks of scales in the younger individual and as isolated scales in the older one and no evidence of the distribution pattern is visible. The scales of Australerpeton cosgriffi are probably exclusively present on the ventral surface, as in Platyoposaurus stuckenbergi (Gubin 1991). There is no evidence of dorsal scales, as in some trematosaurians (Janvier 1992) or dorsal mid line scutes attached to the neural arch as in Eryops (Moulton 1974).

Protection or defense is the most common functional interpretation for the presence of squamation in amphibians. Olson (1979) also proposed that scales could increase the specific gravity in aquatic forms for hydrostatic function and reduce skin drying in terrestrial amphibians. Both functions are plausible for Australerpeton cosgriffi.

The physiological function of the scale covering in fossil amphibians is controversial. For Romer (1972), "the scale covering was such as to exclude the possibility of any great degree of skin breathing in Greererpeton" and he argued that this could be extended for most of the primitive amphibians. $\mathrm{He}$ also proposed that it is not impossible that some primitive amphibians have developed a naked skin, but this feature seems to have appeared later in amphibian evolution.

An opposite idea was presented by Cosgriff and Zawiskie (1979). Studying the dermal bone structure of the rhytidosteid Pneumatostega potamia Cosgriff and Zawiskie 1979. They suggest that the dermal ossifications might have been related to a dermal respiratory apparatus. In this case, not only a well developed honeycombed bone structure is present, but also a dense network of capillary channels connected onto the surface by numerous pores which open to outside in the valleys between the ridge and nodes of the dermal bone sculpture. This network could carry a copious blood supply to a mucous-covered skin where gas exchange was efficiently conducted. Unfortunately, they studied only cranial and shoulder girdle dermal bones, leaving the scales without similar analyses.

Coldiron (1974) argued that there is no consistent relationship between cutaneous respiration and the type of ornamentation of the bone. For him, the dermal bone histology of some labyrinthodonts is a horizontal and irregularly distributed complex of inner vessels, providing an inefficient blood route to the bone surface and then to the skin. He claimed that a more adaptative route should be a less complex pathway, because anastomosed canals do not seem to be related to an effective connection to the epidermis and that, "if the main function of the canals is to carry blood vessels, those of the lower bone layer feeding into this larger middle layer of canals 
would cause a drastic decrease in the blood pressure. This would be very inefficient for rapid blood flow and efficient oxygen exchange at the skin surface" (Coldiron 1974, page 3). Additionally he believed that lungs were the main respiratory apparatus at the labyrinthodont stage and cutaneous respiration would have been impossible.

The scales of Australerpeton cosgriffi show a small number of pores on their external surface. One might expect a larger number if cutaneous respiration was present in those areas.

The dermal bones of the skull and shoulder girdle of $A$. cosgriffi do not show the network of capillary channels described by Cosgriff and Zawiskie (1979), only a single small foramen for each pit or groove (Fig. 3E). Buffrénil (1982) found in crocodilian dermal bones a vascular system similar to that described in temnospondyl amphibians by Bystrow (1935, 1947) and Coldiron (1974). Externally, the dermal bone ornamentation of Caiman sp. shows a similar pattern of a single foramen (or even more than one in some areas) for each pit or groove (Fig. 3F), which is common in living crocodilians. Nevertheless, differences in the morphogenesis of the ornamentation between crocodilians and temnospondyls suggest an independent evolutionary origin for this character. Based on the similarities of dermal skull bones morphology between crocodilians and Australerpeton cosgriffi, and the fact that the former do not breath through their skin, one may conclude that cutaneous respiration was not present in that amphibian. However this does not imply that areas lacking scales and dermal bones could not be sites for this type of gas exchange.

Another function for the complex bone structure of the inner portion of the adult scale could be as a calcium reservoir. The ecologically similar recent animals such as breeding females of african crocodiles do mobilize calcium from the dorsal osteoderms maybe used to make up the egg shells (Hutton 1986). In Australerpeton cosgriffi the resorption and redeposition of bone tissue in the adult scales could be an evidence for calcium reservoir function but hardly related to the breeding season, since amphibians do not lay eggs with shells. Alternatively, calcium remobilization could be related to extreme environmental stress, such as scarcity of food during the dry season. In Trimerorhachis other temnospondyl in which the scale histology is known, bone resorption and redeposition was not observed (Olson 1979). In this case, the scales are not used as a calcium reservoir, and this could be interpreted as evidence for stable environmental conditions.

The ubiquitous presence of Sharpey fibers in the scales of Australerpeton cosgriff is indicative of a dermal origin of the whole scale. Sharpey fibers are unknown in endochondral bone (FrancillonVieillot et al. 1990). Moreover, Sharpey fibers distributed peripherally around the whole scale (Fig. 5A, D and E), indicates that the scales were permanently embedded in skin and strongly anchoraged one to another within the dermis. This can be another evidence against dermal respiration function for the scales of Australerpeton cosgriffi.

The distinctive pattern of dermal bone ornamentation, consisting of grooves and sub-circular pits is typically (but not exclusively) found in poikilothermic amphibious tetrapods. Temnospondyli and Anthracosauria labyrinthodont amphibians, crocodilians, aetosaurs thecodonts, some cotylosaurs (Captorhinidae, Pareiasauridae) frequently show such pits and grooves (Buffrénil 1982). The carapace of the turtle Drazinderetes tethyensis Head, Raza and Gingerich 1999, from the Eocene of Pakistan, also presents superficial bone ornamentation (Head et al. 1999) that is in a way similar to the dermal bone ornamentation found in temnospondyls. The carapace is composed of enlarged ribs which are of endochondral origin. It is not common to this kind of bone to developed superficial ornamentation. In this case, the ornamentation is probably related to anchorage of the dermal scutes. The pattern of bone ornamentation in Australerpeton cosgriffi dermal bones (Fig. 3E) also can be related to skin anchorage or, following Coldiron (1974), a bone-strengthening function.

The process of scale growth in Australerpeton cosgriffi is similar to that of some osteolepiform 
fishes like Gogonasus andrewsae Long 1985 in which only the last-formed layer of laminar material extends around the scale margin onto the articulating surface; internally, as a result of this peripheral growth, the cancellous layer resorbs another laminar layer (Long et al. 1997). Australerpeton cosgriffi shows a marginal growth similar to that seen in Gogonasus andrewsae, but in the latter, the growth affects the whole external surface of the scale, leaving growth lines all around, not only on the border line. At the same time, internally, growth also proceeds by resorption and redeposition of new osteons making up for the expansions of the cancellous compact bone layer. This externally ubiquitous growth of the compact bone also is additional indication that the scales were deeply embedded in the dermis (Fig. 4A-C).

The climatic model for the Rio do Rasto Formation is of semi-arid conditions with a slightly more humid season and a dry and hot season (Ragonha 1989). If each growth line possibly corresponds to a seasonal (annual) growth, then the specimen UFRGS-PV0319P is, by this criterion, at least 5 years old and UFRGS-PV0320P is at least 9 years old. The second could be much older than 9 years but the remodelling of the embryonic scales to form the cancellous bone in the core of the scale precludes an exact count.

It is worth noticing that the remodelling of the scales of this extinct amphibian followed a distinct pattern to those observed in sarcopterygian fishes. In fossil sarcopterygians with cosmoid scales, for instance, reworking affected the topmost layers of the scales, forming the Westoll lines (for an overview see Janvier 1996) and does not affect the embryonic scale area, as we observe in Australerpeton cosgriffi.

\section{CONCLUSIONS}

The most plausible presumed functions for the scales of Australerpeton cosgriffi are calcium reservoir, hydrostatic equilibrium and mechanical protection. The high rate of resorption and remodelling seen in the cancellous compact bone layer is evidence for a calcium reservoir function. Cutaneous respiration is discarded in Australerpeton cosgriffi at least in areas covered by the scales and dermal bones. The distribution of Sharpey fibers around the whole scale is indicative that these scales were strongly anchoraged and deeply embedded into the dermis.

\section{ACKNOWLEDGMENTS}

M. Richter is indebted to Prof. Wolf-Ernst Reif for his hospitality in Tübingen in 1998-99. The thin sections were made by Mrs. Indra Gill-Kopp. The histological study was partially carried out at the Eberhard-Karls Universität Tübingen during a PostDoc by MR sponsored by PUCRS and CNPq (fellowship 20.3461/86-0).

E.V. Dias thanks Prof. Dr. Cesar Leandro Schultz (UFRGS) who made useful comments on the manuscript and MSc. Lílian Timm (UFRGS) for some bibliography and discussions on bone histology of reptiles. CNPq for the financial support (process 143207/1996-2).

The authors also thank Prof. Dr. Vitor Paulo Pereira (UFRGS) for the use of the Optic Microscope Lab (Curso de Pós-Graduação em Geoquímica), Prof. Gerson Terra for the use of the microscope of the Convênio UFRGS-Petrobras, where they completed the histological study and Mr. Luís Flávio Lopes (UFRGS) who developed some of the photographs.

\section{RESUMO}

Escamas abdominais de um espécime juvenil de Australerpeton cosgriffi Barberena 1998 são compostas de osso primário compacto rico em lacunas de osteócitos; canais vasculares e osteons primários são raros, não havendo sinais de remodelamento do tecido por reabsorção e redeposição. Ao contrário, as escamas abdominais de um adulto da mesma espécie mostra um extenso retrabalhamento dos tecidos ósseos. A escama cresce por deposição de osso lamelar perifericamente ao redor de toda sua superfície; a presença de fibras de Sharpey na periferia da escama tanto basal com externamente sugere que elas permaneciam profundamente envolvidas pela derme; a es- 
cama embrionária é completamente remodelada no adulto por reabsorção e redeposição formando uma camada interna esponjosa de osso com grandes baías de erosão e osteons secundários. O remodelamento por reabsorção e redeposição é confinado ao núcleo da escama e não afeta a sua periferia, ao contrário do que acontece nos peixes sarcopterígeos com escamas cosmóides. São discutidas as possíveis funções biológicas das escamas na espécie, tais como proteção mecânica, proteção contra perda d'água, respiração cutânea, controle hidrostático e reserva de cálcio.

Palavras-chave: Temnospondyli, paleohistologia, paleobiologia, Permiano Superior, Formação Rio do Rasto.

\section{REFERENCES}

BARBERENA MC. 1998. Australerpeton cosgriffi n.g., n.sp., a Late Permian Rhinesuchoid amphibian from Brazil. An Acad Bras Cienc 70: 125-137.

BARbERENA MC and Dias EV. 1998. On the presence of a short-snouted Rhinesuchoid amphibian in the Rio do Rasto Formation (Late Permian of Paraná Basin, Brazil). An Acad Bras Cienc 70: 465-468.

Barberena MC, Araújo DC and Lavina EL. 1985. Late Permian and Triassic tetrapods of Southern Brazil. Nat Geog Res 1: 5-20.

Bystrow AP. 1935. Morphologische untersuchungen der Deckknochen des Schädels der Wirbeltiere. Acta Zool 16: 65-141.

Bystrow AP. 1947. Hydrophilous and zenophilous labyrinthodonts. Acta Zool 28: 137-164.

BUFFRÉNIL V DE 1982. Morphogenesis of bone ornamentation in extant and extinct crocodilians. Zoomorphology 99: 155-166.

Contes M. 1996. The Devonian tetrapod Acanthostega gunnari Jarvik: Postcranial anatomy, basal tetrapod interrelationships, and patterns of skeletal evolution. Trans R Soc Edi 87: 363-421.

Coldiron RW. 1974. Possible functions of ornament in labyrinthodont amphibians. Occ Pap Mus Nat Hist Univ Kansas, 33: 1-19.

COSGRIFF JW AND ZAwiskie JM. 1979. A new species of the Rhytidosteidae from the Lystrosaurus Zone and a review of the Rhytidosteoidea. Palaeont Af 22: 1-27.

DAMIANI RJ. 2000. Bone histology of some aus- tralian Triassic temnospondyl amphibians: preliminary data. Mod Geol 24: 109-124.

Dias EV and Barberena MC. 2001. A Temnospondyl Amphibian from the Rio do Rasto Formation, Upper Permian of Southern Brazil. An Acad Bras Cienc 73: 135-143.

FINDLAY GH. 1968. On the struture of the skin in Uranocentrodon (Rhinesuchus) senekalensis Van Hoepen. Palaeont Af 11: 15-21.

Francillon-Vieillot H, Buffrénil V de, Castanet J, Géraudie J, Meunier FJ, Sire JY, Zylberberg L AND RICQUÈS A. DE 1990. Microstructure and mineralization of vertebrate skeletal tissues. In: CARTER JG. (Ed.) Skeletal biomineralization: Patterns, Processes and Evolutionary Trends. 1, Van Nostrand Reinhold, New York, p. 471-530.

Gauthier JA, Kluge AG and Rowe T. 1988. The early evolution of the Amniota. In: The Phylogeny and classification of the tetrapods. Vol. 1; Amphibia, Reptiles, Birds (ed. MJ Benton), Syst Assoc Spec Vol 35A: 103-155.

Graveson AC, Smith MM and Hall BK. 1997. Neural crest potential for tooth development in a Urodele Amphibian: Development and Evolutionary significance. Dev Biol 188: 34-42.

GUBIN YM. 1991. (Permian archegosauroid amphibians of the USSR). Trudy Pal Inst Akad Nauk SSSR 249: 1-138 (in Russian).

Head JJ, Raza SM and Gingerich PD. 1999. Drazinderetes tethyensis, a new large trionychid (Reptilia: Testudines) from the marine Eocene Drazinda formation of the Sulaiman range, Punjab (Pakistan). Contr Mus Paleont Univ Mich 30: 199-214.

Hook RW. 1983. Colosteus scutellatus (Newberry), a primitive Temnospondyl amphibian from the Middle Pensylvanian of Linton, Ohio. Am Mus Nov 2770: $1-41$.

Hutton JM. 1986. Age determination of living Nile crocodiles from the cortical stratification of bone. Copeia 1986: 332-341.

JANVIER P. 1992. Les écailles des Trématosaures (Tetrapoda; Temnospondyli): nouvelles données sur les Trématosaures du Trias Inférieur de Madagascar. Bull Mus natl Hist nat Paris serie 4, 14, section C, 1: 3-13. 
JANVIER P. 1996. Early vertebrates. Clarendon Press, Oxford, $393 \mathrm{p}$.

Konzhukova ED. 1955. Platyops stuckenbergi, Trautschold - an archegosauroid labyrinthodont from the lower zone of the Cis-Uralian Upper Permian. Trudy Palaeont Inst 49: 89-127.

LAURIN M. 1996. A reappraisal of Utegenia, a PermoCarboniferous seymouriamorph (Tetrapoda: Batrachosauria) from Kazakhstan. J Vert Paleont 16: $374-$ 383.

Lebedev OA And CoAtes MI. 1995. The postcranial skeleton of the Devonian tetrapod Tulerpeton curtum Lebedev. Zool J Linn Soc Lond 114: 307-348.

LONG JA, BARWICK RE AND CAMPBELl KSW. 1997. Osteology and functional morphology of the osteolepiform fish Gogonasus andrewsae Long 1985, from the Upper Devonian Gogo Formation, Western Australia. Rec West Aust Mus Suppl 53: 1-89.

Milner AR and Sequeira SEK. 1994. The temnospondyl amphibians from the Visean of East Kirkton, West Lothian, Scotland. Trans R Soc Edinburgh: Earth Sci 84: 331-361.
Moulton JM. 1974. A description of the vertebral column of Eryops based on the notes and drawings of A.S. Romer. Breviora 428: 1-44.

Olson EC. 1979. Aspects of the biology of Trimerorhachis (Amphibia, Temnospondyli). J Paleont 53: 1-17.

Ragonha EW. 1989. Placas Dentárias de Dipnoi no Grupo Passa-Dois (P-Tr) da Bacia do Paraná. Apreciações Ambientais, Climáticas, Cronológicas e estratigráficas. In: Congresso Brasileiro de PAlEontologia, 11, Curitiba, 1989. Anais... Curitiba, SBP. 1: 195-206.

Romer AS. 1956. Osteology of the reptiles. University of Chicago Press. 772p.

Romer AS. 1972. A Carboniferous labyrinthodont amphibian with complete dermal armor. Kirtlandia 16: 1-8.

VAn Hoepen ECN. 1915. Stegocephalia of Senekal. Ann Trans Mus 5: 124-149.

Zylberberg L, Castanet J And De RicQles A. 1980. Structure of the dermal scales in Gymnophiona (Amphibia). J Morph 165: 41-54. 